\title{
The formetric TRACER index: a valid measure of aesthetic deformity in adolescent idiopathic scoliosis
}

\author{
Francesco Negrini, Fabio Zaina, Stefano Negrini \\ From 10th International Conference on Conservative Management of Spinal Deformities - SOSORT 2013 \\ Annual Meeting \\ Chicago, IL, USA. 8-11 May 2013
}

\section{Background}

The gold standard of scoliosis evaluation-Cobb angle measurement-is a valuable tool for assessing spinal deformity and making therapeutic decisions $[1,2]$ but is not fully able to describe the trunk deformity (aesthetics), which is a main concern of patients. Posture, deformity of other bones and soft tissues could be other determinants of the aesthetic impairment due to scoliosis. We do not currently have a commonly accepted measurement of aesthetic impairment due to scoliosis.

\section{Purpose}

The goal of this study was to find a parametric measure to describe aesthetic impairment due to scoliosis. Design: Cross-sectional study. Population: 119 adolescent idiopathic scoliosis (AIS) patients (10.0\% males, age $\left.13.9 \pm 2.3,25.4 \pm 10.9^{\circ} \mathrm{Cobb}\right)$. The sample was randomly divided into two subgroups.

\section{Methods}

Repeated formetric evaluations and simultaneous pictures of the back were performed. An online questionnaire with the photos was completed by 41 laypeople with no scoliosis experience $(53.6 \%$ males, age $30.3 \pm 13.3)$, who judged the photos on a $0-3$ Likert scale (0 normal, 3 highly asymmetric). Statistics: On the first subgroup, we performed a stepwise forward regression technique considering as dependent variable the median of the results of the questionnaire, and as independent variable formetric, clinical and radiological parameters. On the second group, we checked the correlation between the index found (TRACER) and the median of the results of the questionnaire (Spearman's Rho). Finally, we checked the test-retest repeatability (Spearman's Rho), concurrent (Spearman's Rho) and diagnostic (T-test) validity of the index we found.

\section{Results}

The following formula was found: TRACER $=[0.726+$ (CobbMax*0,018)+(SurfaceRotation*0.037) $] / 3 * 100$. This TRACER index $(0-100)$ was well-correlated $(\mathrm{Rho}=0.414$, $\mathrm{p}<0.01)$ with the median of the questionnaire results in the second group; it was also highly repeatable $(\mathrm{Rho}=0.922)$, strongly correlated to Cobb degrees (Rho=0.838), mildly correlated to TRACE index [3] $(\mathrm{Rho}=0.376)$ and distinguished pathological and healthy subjects $(\mathrm{p}<0.01)$.

\section{Conclusions and discussion}

The TRACER index could be used to measure aesthetic deformity in AIS patients; however, further studies are needed to investigate its role in the conservative and surgical treatment of scoliosis.

\section{Published: 18 September 2013}

\section{References}

1. Negrini S, Grivas TB, Kotwicki T, Maruyama T, Rigo M, Weiss HR: Why do we treat adolescent idiopathic scoliosis? What we want to obtain and to avoid for our patients. SOSORT 2005 Consensus paper. Scoliosis 2006, 1:4

2. Donaldson S, Stephens D, Howard A, Alman B, Narayanan U, Wright JG: Surgical decision making in adolescent idiopathic scoliosis. Spine 2007, 32(14):1526-1532.

* Correspondence: stefano.negrini@isico.it

Università Vita-Salute San Raffaele, Milan, Italy

(c) 2013 Negrini et al.; licensee BioMed Central Ltd. This is an Open Access article distributed under the terms of the Creative Commons 
3. Zaina F, Negrini S, Atanasio S: TRACE (Trunk Aesthetic Clinical Evaluation), a routine clinical tool to evaluate aesthetics in scoliosis patients: development from the Aesthetic Index (Al) and repeatability. Scoliosis 2009, 4(1):3.

doi:10.1186/1748-7161-8-S2-028

Cite this article as: Negrini et al:: The formetric TRACER index: a valid measure of aesthetic deformity in adolescent idiopathic scoliosis.

Scoliosis 2013 8(Suppl 2):O28.

Submit your next manuscript to BioMed Central and take full advantage of:

- Convenient online submission

- Thorough peer review

- No space constraints or color figure charges

- Immediate publication on acceptance

- Inclusion in PubMed, CAS, Scopus and Google Scholar

- Research which is freely available for redistribution

Submit your manuscript at www.biomedcentral.com/submit
C Biomed Central 